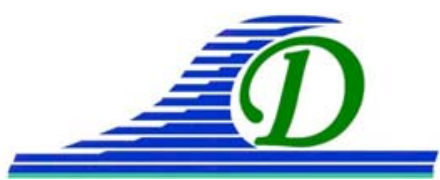

XIII ${ }^{\text {ìmes }}$ Journées Nationales Génie Côtier - Génie Civil

Dunkerque, 2-4 juillet 2014

DOI:10.5150/jngcgc.2014.039 @ Editions Paralia CFL

disponible en ligne - $h$ ttp://www.paralia.fr - available online

\title{
Analysis of mixed-sediment consolidation experiments
}

\author{
Florent GRASSO ${ }^{1}$, Pierre LE HIR ${ }^{1}$, Philippe BASSOULLET ${ }^{1}$
}

\section{IFREMER - DYNECO/PHYSED,}

Centre de Bretagne, BP 70, 29280 Plouzané, France.

florent.grasso@ifremer.fr

\begin{abstract}
:
Estuarine sediment transport models require that a time variation of erodibility due to consolidation be taken into account. If numerical modelling of mud sedimentation and consolidation is currently satisfactory, simulation of mud-sand mixture consolidation is more problematical. This is partly due to mixed-sediment processes, as hindered settling and segregation, not well understood yet. Hence, based on extensive settling columns experiments, the aim of this study is to improve our understanding of mud-sand mixture consolidation for varying concentrations (54 to $600 \mathrm{~kg} / \mathrm{m}^{3}$ ) and large sand contents (15 to $80 \%$ ). Firstly, we observed that for a given initial mass concentration and sand content the final consolidation appeared independent from the initial sediment sample height. For a given initial sand content, the settling phase started earlier for lowconcentrated mixtures and the final consolidation rates ranged between 40 and $90 \%$ for high- and low-concentrated mixtures, respectively. Intriguingly, consolidation tests with the lowest initial mass concentrations led to the largest final mass concentrations. A vertical analysis revealed that for high-concentrated sediments the pore water pressure did not fully dissipate, limiting the entire sediment consolidation. In addition, we observed larger final consolidation rates for larger initial sand contents, leading to larger final mass concentrations. Sand segregation was not always observed in our experiments. Interestingly, the initial relative mud concentration appeared as a potential segregation indicator and of interest to estimate the initial gelling concentration. Finally, these experiments represent a rich dataset to validate numerical modelling of mixedsediment settling and consolidation.
\end{abstract}

Key words: Settling column experiments, Consolidation, Sedimentation, Mud/sand mixtures, Sand segregation, Gelling concentration.

\section{Introduction}

The simulation of cohesive sediments requires that a time variation of erodibility due to consolidation be taken into account (e.g. VAN LEDDEN et al., 2004; SANFORD, 2008; LE HIR et al., 2011). The entire consolidation process, from sediment suspension to compaction, is characterized by different stages, namely: flocculation, settling and consolidation (e.g. IMAI, 1982). This final stage includes a permeability regime, with pore water release, and an effective stress regime, with solid skeleton compression (e.g. 


\section{Thème 2 - Dynamique sédimentaire}

DANKERS \& WINTERWERP, 2007). Sedimentation and consolidation of mud are relatively well understood and numerical model predictions are fairly good (e.g. WINTERWERP \& VAN KESTEREN, 2004; THIEBOT et al., 2011; CHAUCHAT et al., 2013). However, sedimentation and consolidation processes for mud/sand mixtures are more complex. The presence of sand affects the hindered settling of cohesive sediments and mixing or segregation between mud and sand can occur (e.g. MIGNIOT, 1977; TORFS et al., 1996). According to TOORMAN \& BERLAMONT (1993) and HUYSENTRUYT (1995), no segregation occurs for initial mud concentrations above the gel point. However, the concept of gel point is erratic among the scientific community and the gelling concentration is not trivial to be estimated (e.g. DANKERS \& WINTERWERP, 2007), although some authors proposed simplified parameterizations (e.g. VAN RIJN, 2007). Numerical models considering mixedsediment were proposed (e.g. TOORMAN et al., 1999; LE HIR et al., 2011; VAN \& PHAM VAN BANG, 2013), but most of them struggle to simulate accurately sedimentation and consolidation of mud/sand mixtures for large sand contents (>15\%). Calibrating and simulating one settling column experiment is reachable; however for a given model calibration, simulating a dataset characterized by a large variability of initial conditions, as concentration and sand content, is proven more difficult (BARTHOLOMEEUSEN et al., 2002). This may be due to mud/sand interaction processes that remain misunderstood. Hence, based on an extensive dataset, the aim of this study is to improve our understanding of mixed-sediment consolidation for large sand content (>15\%). We ran a large set of experiments with varying initial concentrations and sand contents with the overarching objective to improve the prediction skills of estuarine sediment transport models.

\section{Data and methods}

Sedimentation and consolidation tests were based on 55 settling column experiments (e.g. Figure 1) carried out between 2001 and 2009 with natural sediment mixtures collected in five French bays and estuaries: the Mont Saint Michel Bay (MSMB), the Seine Estuary (SE) and the Penzé Estuary connected to the English Channel, the Bay of Brest connected to the Atlantic Ocean, and the Bay of Marseille connected to the Mediterranean Sea. In this paper, we focused mainly on sediment samples from MSMB and SE. In MSMB, sediment samples came from two different areas, Hirel and Cancale, separated by few kilometers and characterized by different sediment grain size distributions (Figure 1). The initial sand contents at Hirel and Cancale were $n_{s i}=30 \%$ and 15\%, respectively. Experiments started from vertically homogeneous mixtures and were carried out from 20 days to 20 months in order to analyze: (i) the influence of the initial sediment sample height $h_{i}$ (from 10 to $100 \mathrm{~cm}$ ), (ii) the initial mass concentration $C_{i}$ (from 54 to $600 \mathrm{~kg} / \mathrm{m}^{3}$ ) and (iii) the initial sand content $n_{s i}$ (from 15 to $80 \%$ ), on consolidation processes. Consolidation experiments were quantified with the time 


\section{XIII ${ }^{\text {èmes }}$ Journées Nationales Génie Côtier - Génie Civil \\ Dunkerque, 2-4 juillet 2014}

evolution of the sediment sample height $h$, obtained in measuring the sediment-water interface, and the final vertical profiles of mass concentration $C_{f}$, sediment median diameter $d_{50}$, and water content $R_{w}$. The vertically-averaged time evolution of sediment mass concentration was estimated as $C=C_{i} * h_{i} / h$. For further analysis, we computed the initial relative mud concentration that represents the mass of mud in the space between sand (and gravel) grains, which reads:

$C_{\text {relmud. } i}=\frac{C_{\text {mud.i }}}{\left(1-\Phi_{\text {sand } . i}\right)}$

with $C_{\text {mud.i }}$ the initial mass concentration of mud (clay and silt), and $\Phi_{\text {sand. } i}$ the initial volumetric concentration of sand (grain diameter $>63 \mu \mathrm{m}$ ).
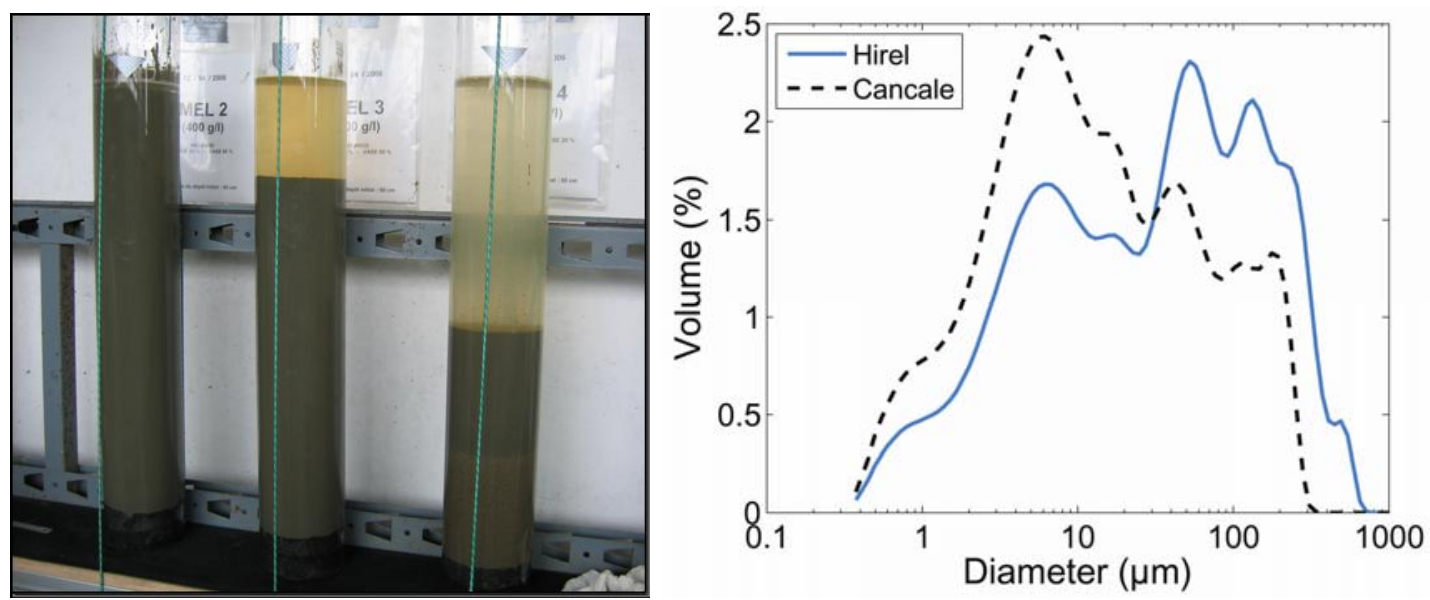

Figure 1. (Left panel) Example of settling column experiments for MSMB - Hirel sediment samples; (right panel) sediment grain size distribution at MSMB for Hirel (solid line) and Cancale (dashed line) sediment samples.

\section{Results}

\subsection{Influence of initial sediment sample height on consolidation processes}

One of the first questions we have in carrying out sedimentation/consolidation experiments in settling columns is the sensitivity of consolidation processes to the initial sediment sample height. Therefore, we compared five settling experiments from MSMB - Hirel during one year with the same initial mass concentration $\left(C_{i}=219 \mathrm{~kg} / \mathrm{m}^{3}\right)$ and varying initial sample heights $\left(h_{i}=10,30,50,75\right.$ and $100 \mathrm{~cm}$ ), as presented in Figure 2. The different phases of consolidation were more readable for taller initial samples (Figure 2a). As an example, for the tallest initial sample (downward triangles, $h_{i}=100 \mathrm{~cm}$ ), the hindered settling phase occurred from 0.03 to 0.25 days, the permeability regime without effective stress from 0.25 to 10 days and with effective stress from 10 days until the end (following DANKERS \& WINTERWERP, 2007). Nevertheless, this is a schematic view and the different regimes interact with each other. 


\section{Thème 2 - Dynamique sédimentaire}

Interestingly, the relative sediment sample height $\left(h / h_{i}\right)$ was almost the same $(\sim 0.3)$ at the end of the five experiments (Figure 3b). Consequently, for mud-sand mixtures with possible segregation, the final consolidation rate ( $70 \%)$ appeared independent from the initial sediment sample height.
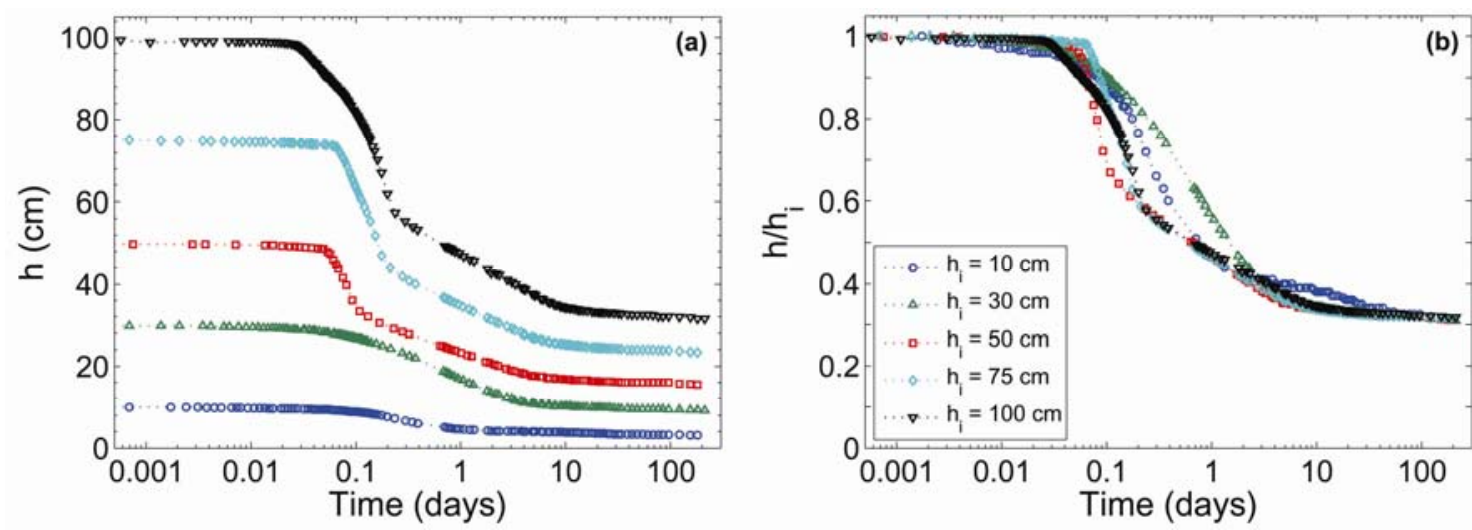

Figure 2. Time evolution of (a) sediment sample height $h$ and (b) relative sediment sample height $h / h_{i}$, for four consolidation tests from MSMB - Hirel with the same initial mass concentration $\left(C_{i}=219 \mathrm{~kg} / \mathrm{m}^{3}\right)$ and varying initial sample heights $h_{i}$.

\subsection{Influence of initial mass concentration on consolidation processes}

We compared long-term (around a year) consolidation experiments from MSMB - Hirel and Cancale with the same initial sediment sample height $\left(h_{i}=100 \mathrm{~cm}\right)$ and varying initial mass concentrations $\left(\mathrm{C}_{\mathrm{i}} \sim 60,110,210,400 \mathrm{~kg} / \mathrm{m}^{3}\right)$, as presented in Figure 3. Although initial sand contents were different in Hirel and Cancale $\left(n_{s i}=30 \%\right.$ and $15 \%$, respectively), results were consistent between the different site locations. Consolidation rates were larger and the settling phase started earlier for low concentrated mixtures (Figures 3a and b). Final consolidation rates ranged between $40 \%$ and $90 \%$ for highand low-concentrated mixtures, respectively. Consolidation experiments with the largest initial mass concentrations (circles, $C_{i} \sim 400 \mathrm{~kg} / \mathrm{m}^{3}$ ) presented only two inflection points, suggesting that no hindered settling phase occurred. Hence, the consolidation of these high-concentrated mixtures would start directly in the permeability regime. Time evolution of sediment mass concentration, estimated according the method presented in Section 2, were investigated (Figures 3c and d). Intriguingly, consolidation tests with the lowest initial mass concentrations led to the largest final mass concentrations. For instance in MSMB - Hirel (Figure 3c), compare the low-concentrated mixture (diamonds, $C_{i}=66 \mathrm{~kg} / \mathrm{m}^{3}, C_{f}=800 \mathrm{~kg} / \mathrm{m}^{3}$ ) and the high-concentrated mixture (circles, $C_{i}=392 \mathrm{~kg} / \mathrm{m}^{3}, C_{f}=720 \mathrm{~kg} / \mathrm{m}^{3}$ ). The vertical analysis of sediment samples at the end of the high-concentrated tests revealed that the mass concentration (solid circles in Figure 4a) increased in the first $25 \mathrm{~cm}$ below the surface $(z>30 \mathrm{~cm}$, where $z=0$ represents the sediment sample bottom), but decreased slightly downward $(z \sim 28 \mathrm{~cm})$. 


\section{XIII ${ }^{\text {èmes }}$ Journées Nationales Génie Côtier - Génie Civil \\ Dunkerque, 2-4 juillet 2014}

It was associated with a local increase of water content (solid circles in Figure 4b). Such a behaviour was even more readable for MSMB - Cancale (solid circles in Figures 4c and d), but it was not observed for lower initial mass concentrations. Thus, during consolidation of high-concentrated sediments water may be "trapped" in depth by a faster surface consolidation, i.e. the pore water pressure did not fully dissipate. It would explain the limited consolidation in the entire sediment sample. Note that this process is currently not taken into account in numerical modelling and could affect consolidation simulations.
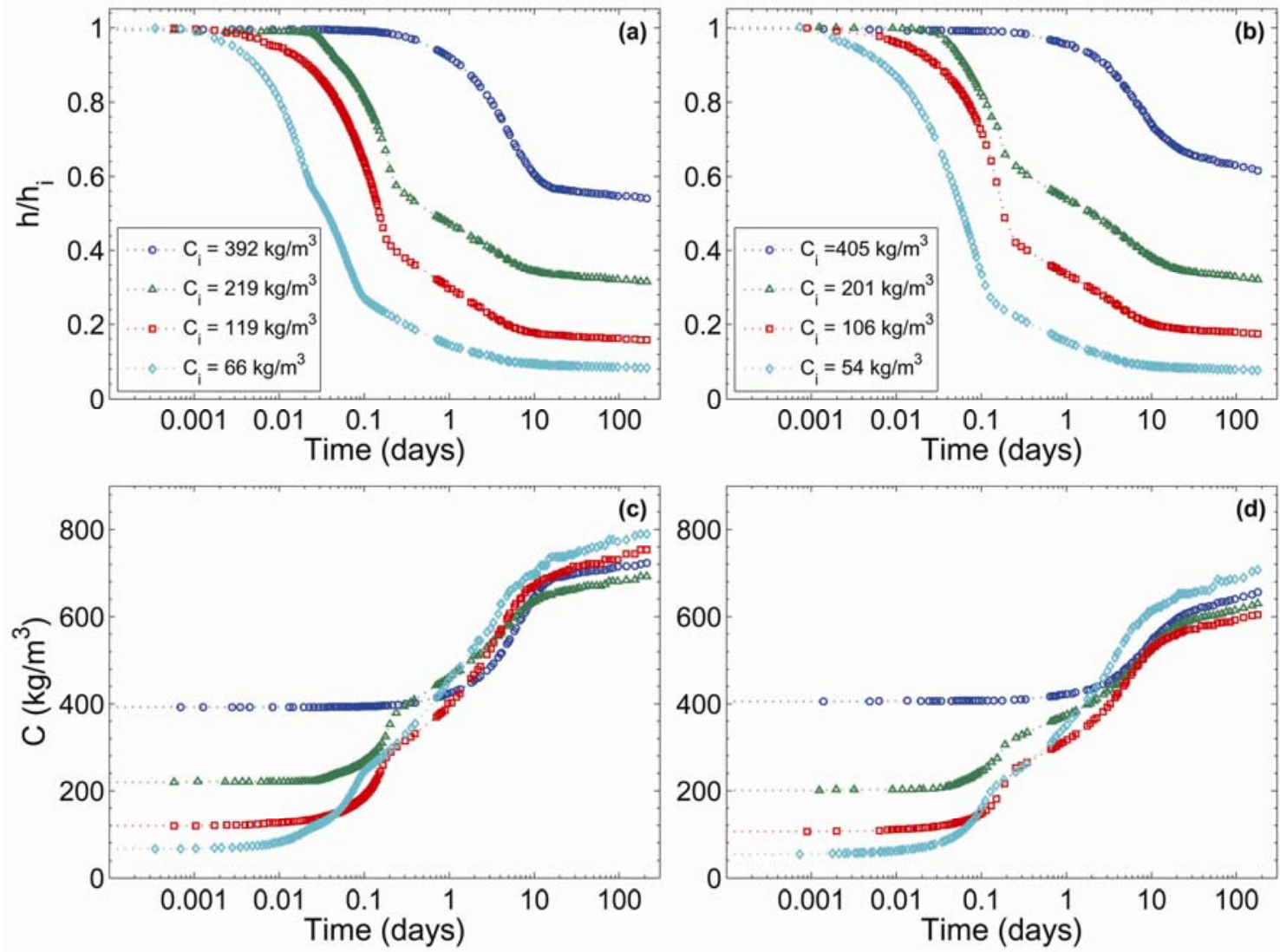

Figure 3. Time evolution of $(a, b)$ relative sediment sample height $h / h_{i}$ and $(c, d)$ vertically-averaged mass concentration $C$, for four consolidation tests with the same initial sample height $\left(h_{i}=100 \mathrm{~cm}\right)$ and varying initial mass concentrations $C_{i}$. Sediment samples from MSMB - Hirel (left panels) and MSMB - Cancale (right panels). 

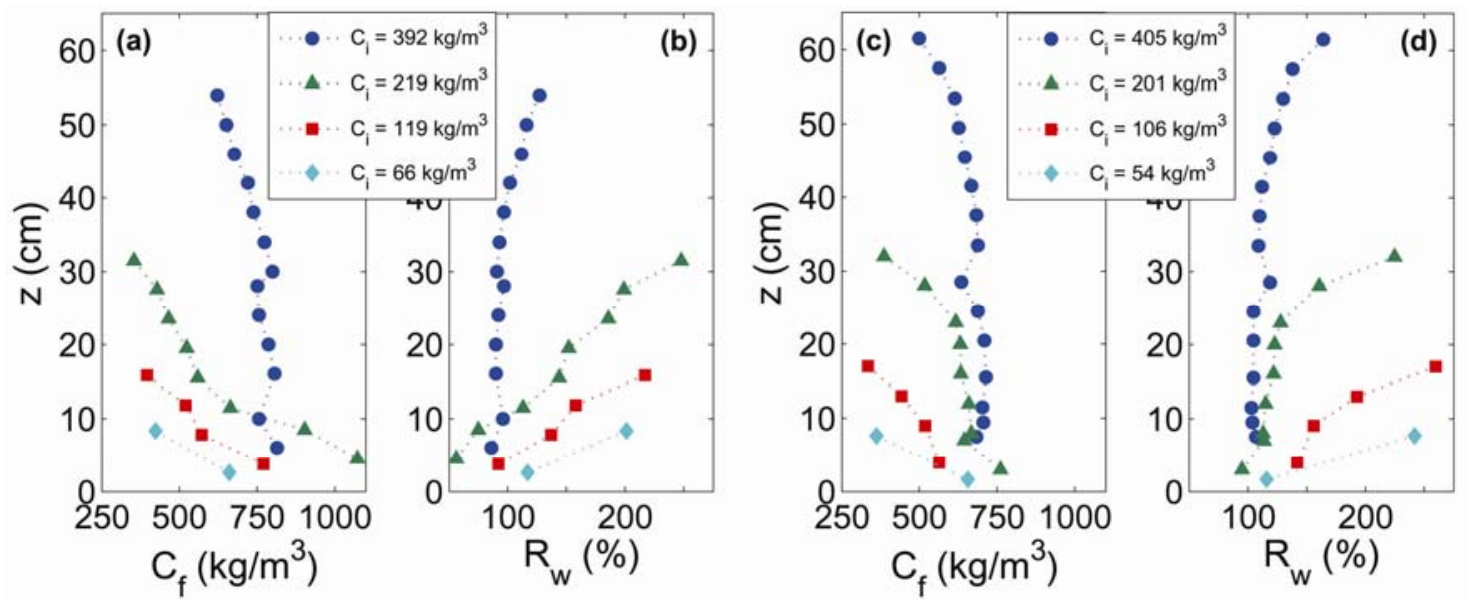

Figure 4. Final vertical profiles of (a,c) mass concentration $C_{f}$ and $(b, d)$ water content $R_{w}$, for four consolidation tests with the same initial sample height $\left(h_{i}=100 \mathrm{~cm}\right)$ and varying initial mass concentrations $C_{i}$. Sediment samples from MSMB - Hirel (left panels) and MSMB - Cancale (right panels). $z=0$ represents the sample bottom.

\subsection{Influence of initial sand content on consolidation processes and segregation}

The influence of sand on mixed-sediment consolidation was analyzed in investigating a range of sand content varying between 15 and 80\%. Comparing consolidation experiments from MSMB - Hirel $\left(n_{s i}=30 \%\right)$ and Cancale $\left(n_{s i}=15 \%\right)$ with similar initial mass concentrations, we observed that final consolidation rates were larger for larger initial sand contents (Figures 3a and b), as observed by TORFS et al. (1996), leading to larger final mass concentrations (Figures $3 c$ and $d$ ). The vertically homogeneous final profiles of mass concentration for high-concentrated mixtures revealed that sand segregation did not occur (circles in Figures 4a and c), i.e. sediment remained mixed. In contrast, the step-like vertical profiles for low-concentrated mixtures was typical of sand segregation (e.g. triangles), i.e. sand below the mud due to faster sand settling.

Natural mud and sand from SE were mixed to obtain mud/sand mixtures with varying initial sand contents (Figure 5). Twenty-day consolidation experiments with $n_{s i}=20$ to $80 \%$ and $C_{i}=200$ to $600 \mathrm{~kg} / \mathrm{m}^{3}$ highlighted similar trends than MSMB experiments. Generally, consolidation behaved similarly in increasing $n_{s i}$ with a constant $C_{i}$ (Figure 5a) or decreasing $C_{i}$ with a constant $n_{s i}$ (Figure 5b). Analyzing final vertical profiles of mass concentration and sediment median diameter (Figures $5 \mathrm{c}$ to $\mathrm{f}$ ), sand segregation was only observed for two experiments (diamonds: $n_{s i}=80 \% \quad /$ $C_{i}=400 \mathrm{~kg} / \mathrm{m}^{3}$ and circles: $n_{s i}=50 \% / C_{i}=200 \mathrm{~kg} / \mathrm{m}^{3}$ ). 


\section{XIII ${ }^{\text {èmes }}$ Journées Nationales Génie Côtier - Génie Civil \\ Dunkerque, 2-4 juillet 2014}
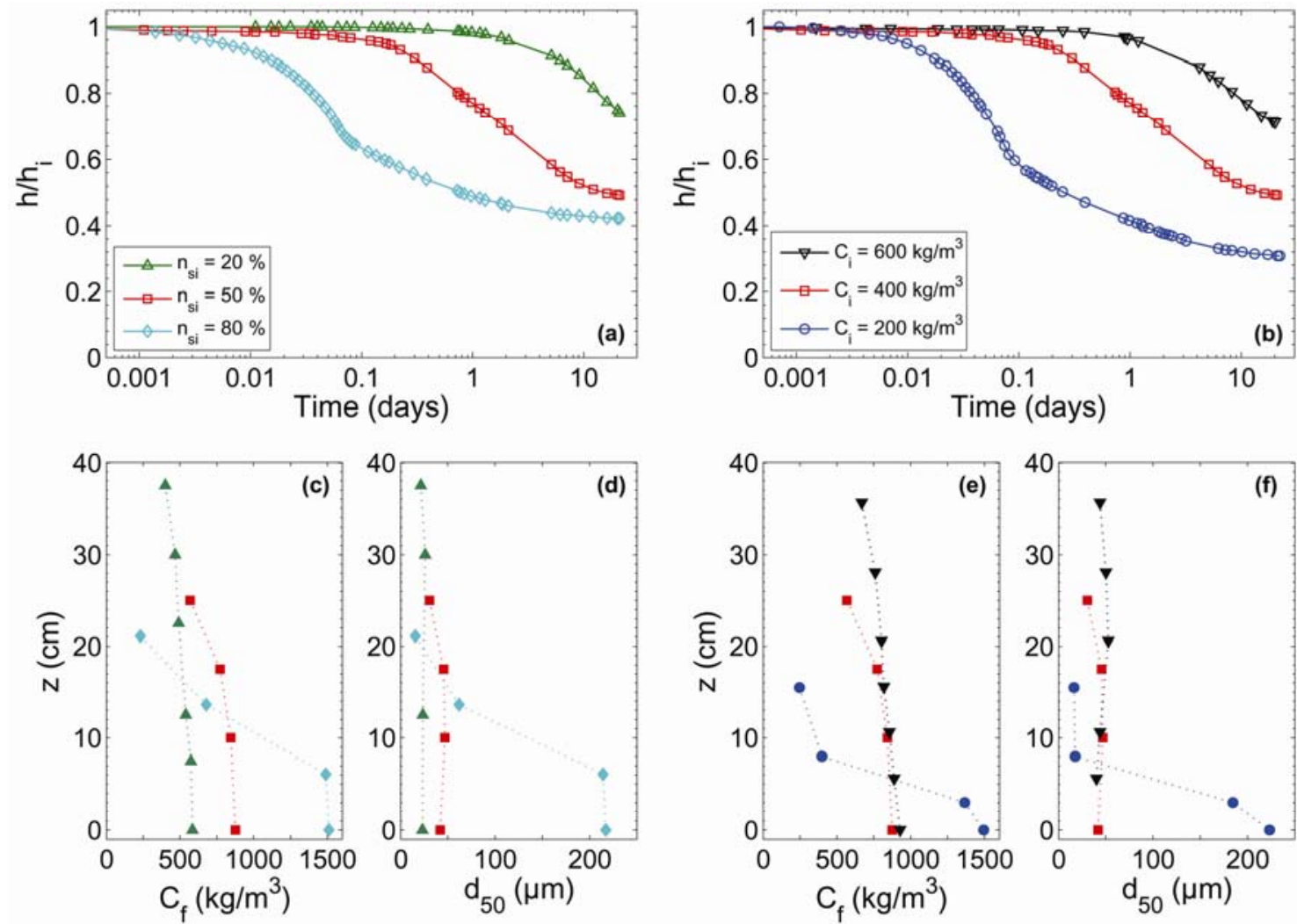

Figure 5. $(a, b)$ Time evolution of relative sediment sample height $h / h_{i}$ and final vertical profiles of $(c, e)$ mass concentration $C_{f}$ and $(d, f)$ sediment median diameter $d_{50}$, for five consolidation tests from $S E$ with the same initial sample height $\left(h_{i}=50 \mathrm{~cm}\right)$. On the left panels (a,c,d), same initial mass concentration $\left(C_{i}=400 \mathrm{~kg} / \mathrm{m}^{3}\right)$ and varying initial sand contents $n_{s i}$; on the right panels (b,e,f), same initial sand content $\left(n_{s i}=50 \%\right)$ and varying initial mass concentrations $C_{i} . \mathrm{z}=0$ represents the sample bottom.

\section{Discussion}

As segregation occurrence depends on sediment mass concentration and sand content, we computed the consistent relative mud concentration $C_{\text {relmud } i}$ (see Section 2) to test if it could represent a pertinent indicator of segregation. This exercise was done for our experiments and some results from the literature, as presented in Table 1. Encouragingly, segregation occurred for $C_{\text {relmud } i} \leq 173 \mathrm{~kg} / \mathrm{m}^{3}$ and not for $C_{\text {relmud } i} \geq 216 \mathrm{~kg} / \mathrm{m}^{3}$. Consequently, $C_{\text {relmud } i}$ seems to represent a good segregation indicator. As it is assumed that no segregation occurs for initial mud concentrations above the gel point (TOORMAN \& BERLAMONT, 1993; HUYSENTRUYT, 1995), $C_{\text {relmud } i} \sim 200 \mathrm{~kg} / \mathrm{m}^{3}$ might be seen as a proxy for estimating the gelling concentration. Unfortunately, we lacked measurements to estimate the gelling concentration from our experiments (e.g. DANKERS \& WINTERWERP, 2007); hence, we need more literature results to challenge this observation. Note that we tried VAN RIJN's (2007) formulation to express the gelling concentration as a function of the sediment median 


\section{Thème 2 - Dynamique sédimentaire}

diameter, but the results were not consistent with the occurrence of sand segregation observed in our experiments. Nonetheless, the combination of the relative mud concentration and the sediment grain size could potentially be a good estimate.

\section{Conclusions}

Long-term (20 to 300 days) sediment settling experiments were carried out with mudsand mixtures from various French bays and estuaries. For a given initial mass concentration and sand content the final consolidation rates were almost independent from the initial sediment sample height. Consolidation rates were larger and the settling phase started earlier for low concentrated mixtures. The consolidation of highconcentrated mixtures may start directly in the permeability regime and water can be hold in depth by a faster surface consolidation, limiting the entire sediment consolidation. For a given initial mass concentration, the final consolidation rates were larger for larger initial sand contents, leading to larger final mass concentrations. Sand segregation was not always observed in our experiments; the initial relative mud concentration appeared as a potential segregation indicator and of interest to estimate the gelling concentration. Finally, these new experiments represent a rich dataset to improve our understanding of mud/sand mixture sedimentation and consolidation and will enable to validate numerical modelling.

Table 1. Description of initial experimental conditions and occurrence of sand segregation after consolidation for settling experiments presented in this paper and from the literature. Tests were sorted in crescent $C_{\text {relmudi } i}$ values.

\begin{tabular}{lcccc}
\hline \multicolumn{1}{c}{ Tests } & $\begin{array}{c}C_{i} \\
\left(\mathrm{~kg} / \mathrm{m}^{3}\right)\end{array}$ & $\begin{array}{c}n_{\text {si }} \\
(\%)\end{array}$ & $\begin{array}{c}C_{\text {relmud } i} \\
\left(\mathrm{~kg} / \mathrm{m}^{3}\right)\end{array}$ & Segregation \\
\hline SE - H & 64 & 17 & 53 & Yes \\
Van \& Pham Van Bang (2013) & 100 & 20 & 81 & Yes \\
MSMB - Hirel 3 & 119 & 30 & 84 & Yes \\
SE - Mel 4 & 400 & 80 & 91 & Yes \\
Merckelbach \& Kranenburg (2004) & 105 & 10 & 95 & Yes \\
SE - G & 117 & 17 & 98 & Yes \\
SE - Mel 1 & 200 & 50 & 104 & Yes \\
MSMB - Hirel 2 & 219 & 30 & 157 & Yes \\
MSMB - Cancale 2 & 201 & 15 & 173 & Yes \\
\hline SE-Mel 3 & 400 & 50 & 216 & No \\
Bay of Brest & 326 & 22 & 258 & No \\
Side 5 (Bartholomeeusen et al., 2002) & 504 & 50 & 278 & No \\
MSMB - Hirel 1 & 392 & 30 & 287 & No \\
SE - Mel 2 & 400 & 20 & 330 & No \\
SE-Mel 5 & 600 & 50 & 338 & No \\
MSMB - Cancale 1 & 405 & 15 & 352 & No \\
Side 6 (Bartholomeeusen et al., 2002) & 781 & 50 & 458 & No \\
Side 1 (Bartholomeeusen et al., 2002) & 795 & 50 & 468 & No \\
Side 2 (Bartholomeeusen et al., 2002) & 870 & 50 & 520 & No \\
Side 3 (Bartholomeeusen et al., 2002) & 893 & 50 & 537 & No \\
\hline
\end{tabular}




\section{XIII ${ }^{\text {èmes }}$ Journées Nationales Génie Côtier - Génie Civil \\ Dunkerque, 2-4 juillet 2014}

\section{Acknowledgements}

The authors want to thank the scientific research programs Seine-Aval III and IV for funding the research projects that enabled carrying out the experiments presented in this study.

\section{References}

BARTHOLOMEEUSEN G., SILLS G.C., ZNIDARCIC D., VAN KESTEREN W., MERCKELBACH L.M., PYKE R., CARRIER W.D., LIN H., PENUMADU D., WINTERWERP H., MASALA S., CHAN D. (2002). Sidere: numerical prediction of large-strain consolidation. Géotechnique, Vol. 52(9), pp 639-48. http://dx.doi.org/10.1680/geot.2002.52.9.639

CHAUCHAT J., GUILLOU S., PHAM VAN BANG D., NGUYEN K.D. (2013). Modelling sedimentation-consolidation in the framework of a one-dimensional twophase flow model. J. Hydrau. Res., Vol. 51(3), pp 293-305. http://dx.doi.org/10.1080/00221686.2013.768798

DANKERS P.J.T., WINTERWERP J.C. (2007). Hindered settling of mud flocs: theory and validation. Cont. Shelf Res., Vol. 27(14), pp 1893-1907. http://dx.doi.org/10.1016/j.csr.2007.03.005

HUYSENTRUYT H. (1995). Consolidation of mud - Settling Column test. Final report for the MAST G8M Coastal Morphodynamics programme, Hydraulics Laboratory, K.U. Leuven, $61 \mathrm{p}$.

IMAI G. (1981). Experimental Studies on Sedimentation Mechanism and Sediment Formation of Clay Materials. Soils and Foundations, Japanese Society of Soil Mechanics and Foundation Engineering, Vol. 21(1), pp 7-20. http://dx.doi.org/10.3208/sandf1972.21.7

LE HIR P., CAYOCCA F., WAELES B. (2011). Dynamics of sand and mud mixtures: a multiprocess-based modelling strategy. Cont. Shelf Res., Vol. 31, pp S135-S149. http://dx.doi.org/10.1016/j.csr.2010.12.009

MERCKELBACH L., KRANENBURG C. (2004). Determining effective stress and permeability equations for soft mud from simple laboratory experiments. Géotechnique, Vol. 54(9), 581-591. http://dx.doi.org/10.1680/geot.2004.54.9.581

MIGNIOT C. (198)9. Tassement et rhéologie des vases, 1ère partie. La Houille Blanche, No 1, pp 11-29.

SANFORD L. (2008). Modeling a dynamically varying mixed sediment bed with erosion, deposition, bioturbation, consolidation and armouring. Comp. Geosci., Vol. 34, pp 1263-1283. http://dx.doi.org/10.1016/j.cageo.2008.02.011

THIEBOT J., GUILLOU S., BRUN-COTTAN J.C. (2011). An optimisation method for determining permeability and effective stress relationships of consolidating cohesive sediment deposits. Cont. Shelf. Res., Vol. 31, pp S117-S123. http://dx.doi.org/10.1016/j.csr.2010.12.004 
TOORMAN E.A. (1999). Sedimentation and self-weight consolidation: constitutive equations and numerical modelling. Géotechnique, Vol. 49(6), pp 709-26. http://dx.doi.org/10.1680/geot.1999.49.6.709

TOORMAN E.A., BERLAMONT J.E. (1993). Settling and consolidation of mixtures of cohesive and non-cohesive sediments. Adv. Hydro-Sci. Eng., Vol. 1, pp 606-613.

TORFS H., MITCHENER H., HUYSENTRUYT H., TOORMAN E. (1996). Settling and consolidation of mud/sand mixtures. Coast. Eng., Vol. 29, pp 27-45. http://dx.doi.org/10.1016/S0378-3839(96)00013-0

VAN L.A., PHAM VAN BANG D. (2013). Hindered settling of sand/mud flocs mixtures: From model formulation to numerical validation. Adv. Wat. Resour., Vol. 53, pp 1-11. http://dx.doi.org/10.1016/j.advwatres.2012.09.009

VAN LEDDEN M., VAN KESTEREN W.G.M., WINTERWERP J.C. (2004). A conceptual framework for the erosion of sand-mud mixtures. Cont. Shelf Res., Vol. 24, pp 1-11. http://dx.doi.org/10.1016/j.csr.2003.09.002

VAN RIJN L.C. (2007). Unified view of sediment transport by currents and waves. I: initiation of motion, bed roughness, and bed-load transport. J. Hydrau. Eng. , Vol. 133(6), pp 649-66. http://dx.doi.org/10.1061/(ASCE)0733-9429(2007)133:6(649)

WINTERWERP J.C., VAN KESTEREN W.G.M. (2004). Introduction to the Physics of Cohesive Sediment in the Marine Environment. Elsevier, New York, 466 p. 